\title{
Developing the Scholarship of Teaching and Learning at One University of Technology in South Africa
}

\author{
Prof. Irene Ntombikayise Moutlana \\ Vice Chancellor's Office, Vaal University of Technology \\ Vanderbijpark 1900, South Africa \\ Email:moutlana@vut.ac.za
}

Prof. Kholeka Constance Moloi

Vaal University of Technology, Faculty of Human Sciences Vanderbijlpark 1900, South Africa Email: conniem@vut.ac.za

Doi:10.5901/mjss.2014.v5n1p51

\begin{abstract}
Man's quest to know, understand and navigate comfortably in an increasingly complex environment has become the single most visible driver of the $21^{\text {st }}$ century academic revolution. The new quest for meaning-making and knowing how has become pivotal in the massification of Higher Education (HE) systems in South Africa, under the rubric of the public versus the private good. Similarly, notions of the scholarship of teaching and learning (SoTL) have impacted the conditions of the knowledge economy and the repositioning of HE within the global knowledge village, which sees neither boundaries nor limits. Premised on the belief that teaching is a scholarly activity to be valued as community property, one of the most important goals of SoTL is to foster significant, long-lasting learning for all students while simultaneously bringing recognition and reward to teachers who practise evidenced-based teaching. The philosophy behind SoTL acknowledges that students and universities of technology are best served when teachers practise scholarly teaching, and that no one is better situated to conduct the scholarship of teaching than those engaged with students on a regular basis. In this theoretical exploration, the authors examine how the scholarship of teaching and learning can be developed in one university of technology in South Africa, situating their work within studies that describe SoTL in the context of specific disciplines.
\end{abstract}

Keywords: scholarship of teaching and learning; multi-disciplinarity; educational disciplines; evidence-based teaching, University of Technology

\section{Introduction}

The rationale for this theoretical exploration proceeds from the number of challenges experienced in higher education in South Africa, including unsatisfactory completion rates in undergraduate and postgraduate studies, particularly at the institution under study. Analysis of higher education performance by the CHE Task Team (2013: 33) has shown serious shortcomings in recent years in graduate output and outcomes, including the following:

- Low student success and throughput rates, leading to low absolute numbers of graduates.

- Uneven and often unsatisfactory graduate quality, not only in disciplinary or technical expertise but in graduate attributes that are widely seen as necessary for the contemporary world.

- The highly skewed distribution of graduates along racial lines.

- The interlocking conditions of low output and lack of equity, which have a major effect on all forms of development.

According to the CHE Task Team (2013: 52), the performance described above shows that higher education is not meeting the country's needs in respect of equity and social cohesion. The persistence of substantial inequalities in both participation and success means that the benefits of higher education continue to be inequitably distributed. In this regard, the National Planning Committee (NPC) states that, for the increase in the number of graduates to be meaningful, the quality of education needs to improve because the data on the quality of university education are disturbing (2012: 317). According to the CHE Task Team (2013:52), the onus on higher educational institutions is to assume greater responsibility for achieving the qualitative transformation reflected in the missions of many, but now 
requiring their urgent realisation because true transformation of the current challenges will occur in the field of teaching itself through scholarship. Little, Locke, Parker and Richardson (2007:2), however, argue that it is clear that the dynamics of the relationship between teaching and learning are mediated by students' own perceptions of their environment and by their own motivations for learning and that excellence in student learning may or may not require excellent teaching.

Research by McKinney (2004:3) indicates that the scholarship of teaching and learning is a fairly recent philosophy that has been adopted by scholars and researchers from various disciplines, including educational psychology and various educational disciplines, as well as specialists in various disciplines who are interested in improving teaching and learning in their respective fields. Healey (2000:171) asserts that the scholarship of teaching involves engagement with research into teaching and learning, critical reflection on practice, and communication and dissemination of aspects of the practice of one's subject. Expanding the latter, Green and Little (2013:254) argue that scholarship neither orientalises nor colonises other disciplines despite the fact that they do not fit the social-scientific orthodoxies of higher education pedagogy. Premised on the belief that teaching is a scholarly activity to be valued as community property, one of the most important goals of SoTL is to foster significant, long-lasting learning for all students while simultaneously bringing recognition and reward to teachers who practise evidenced-based teaching (Hutchings, Huber \& Ciccone, 2011:1). The philosophy behind SoTL acknowledges that students and universities of technology are best served when teachers practise scholarly teaching, and that no one is better situated to conduct the scholarship of teaching than those engaged with students on a regular basis (McKinney, 2004:5).

Scholarly teachers are well versed in pedagogical content knowledge (PCK), which identifies distinctive bodies of knowledge for teaching (Shulman 2005:52). PCK also represents the blending of content and pedagogy into an understanding of how particular topics, problems or issues are organised, represented and adapted to the diverse interests and abilities of learners and presented for instruction. In an attempt to address the development of the scholarship of teaching and learning at the University of Technology under study, important questions posed in this paper are:

- How does active learning in large classes influence students' comprehension of the learning content?

- How are pedagogical spaces for learning provided for in our classrooms?

- What and how do assignments contribute to student learning in a course or programme?

- How responsive at the epistemological level are the knowledge systems in our classrooms?

- What dominant intellectual discourse permeates our teaching and learning practices?

- How do we objectify knowledge in terms of our own epistemological and ontological positions as teachers and facilitators of student learning?

- How do we use students' cultural wealth and social life to mediate their academic experiences?

SoTL addresses these questions by systematically examining student learning with the aim of improving educational processes and the practices of teachers in higher education (Green \& Little, 2013:523). Research by Portes (2005:5) indicates that, despite the overwhelming pressures of the external environment, the majority of higher education students are said to be able to use institutional activities as a support for healthy adjustment and achievement when universities are sensitive to their needs and their burdens, particular with better teaching. Indeed, as purported by Gibbs \& Habeshaw (2002:5), good teaching is teaching which helps students to learn and encourages high-quality student learning. It discourages the superficial approach to learning and encourages active engagement with the subject matter. This does not imply that good teaching always results in high-quality student learning but that it is designed to do so and that it is practised in a way likely to lead to high-quality learning. Good teaching is that which encourages in the learner, no matter what the subject content, motivation to learn, desire to understand, perseverance, independence, a respect for the truth and a desire to pursue learning.

We argue that one way of addressing students' needs is by developing and institutionalising the scholarship of teaching and learning. In this regard, Skelton (2005:73) has argued that, however excellent individual teachers may appear to be, their work is always located in a broader institutional context. He points out that the availability of professional development courses for teachers, the formal recognition of teaching in promotions procedures and the introduction of teaching-related promotions to new posts will encourage the development of scholarship within an institution. This provides a challenging transformative agenda for the development of subject-based teaching supported by an affirming culture of excellence. Implementing this agenda includes applying the principles of good practice in the disciplines, developing the status of teaching, developing the complementary nature of teaching and research, and undertaking discipline-based pedagogic research in order to improve and enhance the quality of the student learning experience. 


\section{Mapping the Context of the Higher Education Environment in South Africa}

Portes (2005:4) has argued that an understanding of the main obstacles to excellence and equity in education depends in great part, on grasping the complex nature of how social inequality is socially organised and sustained. He goes on to say that teachers today need a common knowledge base to help dismantle a system that reproduces inequality and hinders excellence. The authors fully agree with Portes' assertions. Considering that students at South African higher education institutions come from a variety of racial, cultural, linguistic and socio-economic backgrounds that differ greatly from those of their teachers, such cross-cultural interactions and differences, even if mutually satisfying, may result in educational experiences and outcomes not being successfully achieved. Added to this complexity is the fact that the student population at all levels of higher education is apparently becoming multi-cultural and multi-racial at a faster rate than are teachers and other institutional personnel. It is this increase in diversity among the student population that is posing the greatest challenge to advocating the equal opportunity maxim at the institution under investigation. On the other hand, teachers in such diverse settings also bring with them hopes and dreams, but they soon learn that they must walk a tightrope between a variety of conflicting education demands and issues.

Given our segregated educational history, most black students move into these desegregated institutions in what Hooks (1990:342) calls a state of marginality - which is more than just a site of deprivation, but also the site of radical possibility, a space of resistance. The diverse, complex, contradictory and highly contested higher education context, which is unequal in terms of material, intellectual, academic, social and financial resources, does not make it easy to provide quality education for all students. The current inequalities in higher education and the social, economic and political structures of society continually reproduce marginality for those who are already underprivileged (Portes, 2005:5). It is this marginal state that can be painfully misinterpreted, leading to incoming students being labelled in most undesirable ways. These potential tensions or conflict zones make sound counselling and academic development programmes in our diverse and multicultural settings an imperative and emphasise, in particular, the need to develop the scholarship of teaching and learning so that we can improve educational processes and our own teaching practices. A challenge that is central to South African higher education, and that cuts across the main structural shortcomings of current curricula, is the need to deal constructively with diversity in students' educational, linguistic and socio-economic backgrounds (CHE Task Team, 2013:19). In the light of this, Green and Little (2013:523) assert that pedagogies depend on context and that no panacea can solve the difficulties of teaching and learning.

Research by the CHE Task Team (2013: 15) points out that South Africa has a pressing need for more graduates of good quality to take forward all forms of social and economic development. The country also needs more graduates to build up the education system itself by providing a strong new generation of teachers, college teachers, academics and education leaders. However, South Africa's graduate output has been found to have major shortcomings in terms of overall numbers, equity, and the proportion of the student body that succeeds. Despite a small intake in higher education that has good academic potential, performance in higher education is marked by high levels of failure and dropout, as illustrated below.

- Only about one in four students in contact institutions (that is, excluding the University of South Africa - an open distance university) graduate within the required time (for example, three years for a three-year degree).

- Only $35 \%$ of the total intake, and $48 \%$ of contact students, graduate within five years.

- When allowance is made for students taking longer than five years to graduate or returning to the system after dropping out, it is estimated that some $55 \%$ of the intake will never graduate.

- Access, success and completion rates continue to be racially skewed, with white completion rates being on average $50 \%$ higher than African rates.

- The net result of the disparities in access and success is that under 5\% of African and coloured youth (mixed blood) are succeeding in any form of higher education (CHE Task Team, 2013: 15).

These performance patterns are not compatible with South Africa's need to develop economically in order to address the unemployment and poverty pervasive in the country. The conclusions arrived at by the CHE Task Team (2013:15) are that the output of higher education is not meeting the country's needs, that the system has low internal efficiency in utilising human and material resources (and consequently does not provide a sound basis for growth), and that the scale of the failure and dropout occurring within a small and selected student body points to substantial systemic problems that require systemic responses. According to Fisher \& Scott (2011:1), in relation to its educational role, higher education in South Africa is a 'low-participation, high-attrition system' that has not yet come to terms with its developingcountry environment. The CHE Task Team (2013) fully acknowledges the effects of material (especially financial) and affective factors on learning, but is determined that academic factors are at the heart of the systemic obstacles to student 
success. The Task Team's investigation has identified curriculum structure as a key framework that enables or constrains effective teaching and learning in higher education.

Higher education institutions are known as the slowest institutions to change amidst major external turbulence or events; at times one may think that the more things change, the more higher education institutions subtly resist change. However, we can safely argue that in recent decades there has been a remarkable change in the discourse of education, resulting in deep and fundamental changes that have shaped the academic enterprise for decades to come. Hence the concept of academic revolutions will be pivotal in the attempt to create the logical educational 'politik' linking scholarship, teaching and learning. Such an endeavour for the scholarship of teaching and learning should be reflected in our individual teaching philosophies. A teaching philosophy is a self-reflective statement of our beliefs about teaching and learning. These beliefs should be put into practice by including concrete examples of what we do or anticipate doing in our classrooms.

Could it be that this exaggerated imposing of the cultural difference ideology has prevented teachers and administrators in general from acquiring the necessary training to deal competently and effectively with a diverse student population? Such obvious shortcomings in our learning and teaching environments have made both parents and students very vocal in expressing concerns about the learning opportunities offered by higher education institutions. These concerns have brought into question the integrity and value of institutions in fulfilling the promise of giving a fair chance to all our students. Since universities are assumed to represent the convictions of a society, it is in them that we partly see a way out of our dilemma. This dilemma is based not so much on numbers, as institutions' doors are thrown wide open, but on full acceptance of our diversity - which has had important implications for conceptualisations that are relevant to both the teaching and learning of different people from different cultural orientations within the same classroom - while still attempting to keep our promise that all children, by virtue of their own efforts, when competently guided, can hope to attain the mature and informed judgement needed to manage their own lives, thereby serving not only their own interest, but also the progress of society itself. What is at risk here is the fulfilment of the promise of equal opportunities for all. It is against the backdrop of these challenges that we attempt to explore both how SoTL can be developed at the University of Technology under study and the need for self-definition in the face of internal and external challenges (Green \& Little, 2013:524).

\section{Literature Review on the Scholarship of Teaching and Learning}

The scholarship of teaching and learning involves inquiry into teaching, engagement, feedback and reflection on teaching and learning and the sharing of results so that others can review, critique and build on the work (Elton, 2001:43). For Shulman (2005), the discourse on the scholarship of teaching is often linked in the literature to two other notions: teaching excellence and the expert teacher. The expert teacher is one who not only 'knows' the subject matter being taught and knows 'how' to teach, but also knows how to transform the particular subject being taught into terms that students can understand. Pivotal to the notion of SoTL is a deep understanding of the subject content that one teaches and an unceasing process of inquiry by the teacher (Elton 2003:7). Expanding this notion, Kreber (2002:18) argues that scholars of teaching are both excellent teachers and expert teachers, but what distinguishes them as scholars of teaching is the fact that they share their knowledge and advance the knowledge of teaching and learning in the discipline in a way that can be peer-reviewed. SoTL is thus scholarly inquiry into student learning which advances the practice of teaching by making research integral to teaching (Healey, 2005:33). In this regard, SoTL builds on many past traditions in higher education, including classroom and programme assessment, action research, the reflective practice movement, peer review of teaching, traditional educational research, and faculty development efforts to enhance teaching and learning (Hutchings, 2002).

According to Mckinney (2004:5), terms closely related to the scholarship of teaching and learning are good teaching (that which promotes student learning and desired outcomes and is recognised by student satisfaction and peer reviews, for example) and scholarly teaching (in which teaching is regarded as an area of study and the teaching and learning knowledge base is regarded as an additional discipline in which to develop expertise) (Elvidge, 2004:84). To this end, Shulman (2001:8) points out that the transformation of subject matter for teaching occurs when the teacher critically reflects on and interprets the subject matter and then finds multiple ways to represent the information as analogies, metaphors, examples, problems, demonstrations and classroom activities. Reflective teachers are also able to adapt learning material to students' abilities, gender, prior knowledge and preconceptions.

Such an approach to good teaching promotes student learning and other desired student outcomes. We argue that within the context of university under study, scholarly teaching will emerge if it is supported by department plans and 
programmes, institutional missions, vision and strategic objectives. Our view is in line with the assertion of Gibbs and Habeshaw (2002) that, in each institutional context, the recognition and rewarding (and therefore the definition) of excellence ought to be tied to strategic institutional goals, such as widening participation, student retention and engagement with employers. According Zubrick, Reid and Rossiter (2001:88), the rewards go beyond one-time acknowledgement of excellence. Master teachers, they purport, like distinguished researchers, provide a valuable resource to the university in addressing the educational needs of the university, and become an integral part of the university's strategic planning efforts to shape learning.

Scholarly teaching involves taking a scholarly approach to teaching, just as we would take a scholarly approach to other areas of knowledge and practice such as research projects within the faculty (McKinney, 2004:3). According to Boyer (1990: 2), scholarly teachers view teaching as a profession and the knowledge base of teaching and learning as a second discipline in which to develop expertise. Consequently, scholarly teachers are reflective practitioners (Schon, 1983; Brookefield 2005) who use classroom assessment techniques, discuss teaching issues with colleagues (learning together), try new things, and read and apply the literature on teaching and learning in their classrooms. Glasner (2003:13) posits that, at the individual level, excellence is not possible without both work and intelligence. It requires learning from others as well as learning about oneself. It requires an understanding of the institutional context within which one works so that students are engaged, inspired and motivated and the resources and opportunities provided by the institution are effectively utilised.

The scholarship of teaching and learning is an investigation of a problem relating to teaching or learning and the public sharing and review of such work through presentations or publications (Healey, 2005:35). The study of the problem is conducted by means of methods appropriate to disciplinary epistemologies (e.g. quasi-experimental design, case studies), and the results are communicated to peers for critical reflection through journal articles, conference presentations, and online delivery (Kreber, 2005:6). SoTL, then, shares the established criteria of scholarship in general, in that it is made public, can be reviewed critically by members of the appropriate community, and can be built upon by others to advance the field (McKinney, 2004:3). 'Study' in this context is broadly defined, given disciplinary differences in epistemology and the need for interdisciplinary SoTL (Breslow, Drew, Healey, Matthew \& Norton, 2004:84). Green and Little (2013:525) point out that interdisciplinarity emerges from the interstices between established disciplines, and it continues to gain currency as an indicator of a thriving intellectual community.

Being an effective and excellent teacher requires reflection and an active and imaginative engagement with the mission of the institution and with individual students. The outstanding teacher is passionate in the pursuit of enabling others to learn. But the best, the most outstanding, teachers cannot and do not operate in a vacuum, and an institution that is unfocused or confused about its mission can make an outstanding teacher ineffective. Excellent teachers are not born; they develop and grow in a supportive environment (Glasner, 2003:13). From this perspective, argue Hutching and Shulman (1999: 10), teaching can be approached as a form of scholarly work, providing a setting in which members of the faculty frame and systematically investigate questions related to student learning, the conditions under which it occurs, what it looks like, how to deepen it and to do so with an eye not only to improving their own classroom but to advancing practice beyond it. We argue that it is such concerns that are forcing teachers to focus on how to create a learning environment responsive to the needs of students from diverse cultural and racial backgrounds.

Joshee (2008:32) contends that in recent years new diversity discourses built on the logic of neoliberalism have entered the educational policy domain. Thus, to facilitate SoTL at the institution, we need to continually engender the enhancement of students' educational and social development by collaborating on both the content and the pedagogy of the courses as well as on social justice programmes in order to ensure responsive education. Apple (2004:xii) asserts that responsive education struggles with existing constraints to construct transformative policies, pedagogies and politics that enable intergenerational engagements with changing global and local imperatives and a very real commitment to creating education institutions that are closely connected to a larger project of social transformation. According to Joshee (2008:32), such an approach to education creates the space for policy actors, including teachers, to challenge the dominant neoliberal ideology. Zeichner and Flessner (2009:27) further this line of thought by arguing that teaching for social justice includes strong preparation in academic content knowledge and instructional, assessment, relational, and management skills needed to translate that knowledge to students in a way that promotes understanding. For Joshee (2008:32) such a reconstructionist project engenders social justice discourses that provide space for resisting and subverting neoliberal ideology. These issues focus on reconstructing the family, degendering societal institutions, using science and technology for sustaining ecological and multiculturally diverse forms of life, and integrating humanity and nature on the basis of a sociobiological identity (Zeichner \& Flessner, 2009:27). These sorts of engagements and narratives enable students to situate themselves self-consciously and tactically within the inter-dependent, multi-layered 
practices of ecological, economic, cultural and socio-political globalisation and localisation (op.cit.).

Zeichner \& Flessner (2009:26) assert that teachers who are committed to scholarship and the social justice agenda:

- are socio-culturally conscious and recognise that there are multiple ways of perceiving reality that are influenced by one's location and historicity in the social order;

- have an affirming view of students from diverse backgrounds and see resources for learning in all students rather than viewing differences as problems to overcome;

- see themselves as both responsible for and capable of bringing about educational change that will make higher education institutions responsive to all students;

- understand how students construct knowledge and are capable of promoting students' knowledge construction;

- know about their students' lives, including the funds of knowledge in their communities;

- use their knowledge about the lives of their students to design instruction that builds on what they already know while stretching them beyond the familiar.

These visions of the culturally responsive teachers go beyond a celebration of diversity. In their elaborated forms they explicitly address issues of oppression and injustice that are linked to social class, race, gender and other markers of difference that are embedded in the institutions and structures in a society, as well as in the minds of individuals (op.cit.). They also include an activist component that encourages teachers as agents of change to act within and outside of institutions to combat these injustices. Boyer (1990:1) postulates that scholarship is not an esoteric appendage. Rather, it is the heart of what the teaching profession is all about. This means that all faculty staff should themselves, throughout their careers, remain students - that is, life-long learners. As progressive and socially critical teachers we are required to continue to learn and be seriously and continuously engaged in expanding the intellectual world by being in touch with parents and our local communities (Apple, 2004:xii).

\section{Developing Scholarship within the University of Technology}

The authors believe that when we empower ourselves as an academic community we will be able to help deal with major economic, societal and environmental issues by developing an ethos and skills for effective teaching and learning because education cannot escape being influenced by these forces (Arshad-Ayaz, 2008:480). To develop scholarship it is imperative that excellent teachers are given recognition and rewarded. According to Little, Locke, Parker and Richards (2007:20), excellent teachers who have been recognised and rewarded will take on wider roles than just teaching and, for example, seek to innovate, initiate change, mentor and even provide academic leadership. Our mandate and moral obligation as progressive teachers is to be responsive to the changing and demanding needs of society and of our students, especially because we draw students from poor communities. Today's job market shifts rapidly with changes in technology in the local and global economy and, as employment opportunities for qualified university graduates fluctuate, we need to change the way we teach in our classrooms accordingly in order to provide quality education and human development that fosters the values of social justice and care (Portes, 2005:6). This is in line with human rights in education, which promulgate the notion of civil and political rights, social, economic and cultural rights as well as the right of solidarity.

Thus in the context of the institution under study, to develop the scholarship of teaching and learning, we should continually reflect on the following:

- How do my students learn in my classroom?

- How do I learn in order to enhance student learning and success in my classroom?

- How is the teaching-research nexus fostered in my department in order to develop the scholarship of teaching and learning?

- Do I have the necessary support to develop the scholarship of teaching and learning?

- Who are my mentors within the department, faculty and institution?

- What are the best practice models of the scholarship of teaching and learning that inform our own design efforts?

At a university of technology, the concept of scholarship can be very seductive if not misleading at times. It is argued that the new technologies have facilitated revolutionary changes in organisations, churches, families and, above all, universities (Joshee, 2008:320). Underpinning all these accelerated changes is the emergence of knowledge as a 
dominant property (Brooks-Buck, 2008:117). Historically it is maintained that knowledge has always played an important role in human, economic and social development, but sadly enough has not served as the driving force behind the evolution of the political economy. Indeed, as argued by Arshad-Ayaz (2008: 480), 'globalisation in terms of economic, political, social and cultural transformations cannot be unproblematically beneficial to all citizens, societies or cultures'. Today, economic success is determined largely by the legitimised power of knowledge, and by the quality and relevance of the information one possesses. Indeed, the most successful organisations and individuals are those that are innovative and capable of constantly reinventing themselves to better serve the evolving needs of society.

While much about being a university Professor has remained unchanged over the decades, the advent of Social Media has, in all its forms, posed the greatest threat to the professorial mind and voice. The amount of discomfort within the classroom is mounting as the custodians of knowledge, teaching, and learning are compelled to change, so as to experience the liberating effect new technologies have on their stomping grounds. The game is the same, but the rules are changing fast. Can these new requirements return scholars to the position of public intellectuals and how long will this last? Or will academics feel safer in their ivory towers? Andy Miah (2012:1) captures this sense of professorial unease as follows: '...social media is undergirding the entire architecture of the scholarly web of today.' There is no place to hide for us anymore. As academics in a digital era, we cannot escape the impact or influence on our scholarship by technology. In light of this, Green and Little (2013: 254) argue: 'Universities are depicted as Balkanised territory, when competing factions stake their claim on plots of land, defending borders and attempting to annex others.'

In an effort not be an outsider within the scholarly mindset, many professors are now venturing into creating their own websites. On the other hand, as far as teaching and learning is concerned, students' expectations are fast changing. Gone are the overhead projectors with their plastic acetates. Students are now expecting contents to be delivered digitally. They expect their teachers to use social media platforms, and to be immediately available for consultations, which presents a unique challenge. Even our faithful PowerPoints are fast becoming antiques as new platforms like mind-mapping software are changing the way that content is delivered and experienced. While the traditional academic associations with their compulsory annual fees and poster sessions still remain commonplace, the question is: in view of the speed with which technology is turning learning and teaching upside down, will we still have relevance or authority in a more fluid academic era? Only time will tell.

Academic mobility has become the hallmark of the global age and our knowledge society. ICT, as one of our greatest competitors in knowledge creation, has the most powerful influence on education. Hence the impact of technology on scholarship, teaching and learning, internal processes and procedures of university has been very profound. ICT has broadened the gap in scholarly inequalities between the haves and the have-nots. Our $21^{\text {st }}$ century knowledge economy, focusing on the increasing importance of the service sector, a growing segment of the workforce, has called into question our long-held beliefs in education as the single most important upward social elevator in terms of teaching, learning relevance and application, above all the benefits of a scholarly mindset. We are further threatened by instantaneous communication, global dissemination of research (double victory partnerships) and the use of English as the world's language to help us make smooth inroads into $21^{\text {st }}$ century knowledge with society. In our pursuit of education for the public good, which easily translates into massification, the latter sounds very noble; it can be very seductive and, if not checked, all of us will be moving in the wrong direction. It is argued that inherent in such a progressive maxim, that is, massification of the public good, lie deep contradictions: on the one hand, a lowering of academic standards, or, on the other, greater social mobility for a growing segment of the disadvantaged or the forgotten half of society.

This is further compounded by the impact of globalisation in terms of the relevance, breadth and depth of the academic enterprise (Arshad-Ayaz, 2008:481). For example, academic activities, roles and the academic profession itself are compelled to become more internationally oriented, more mobile, yet still structured in terms of national imperatives. Furthermore, our activities as academics are becoming more diversified and specialised. As a developing country with an unequal educational past, our academic qualifications may not improve much as a result of dwindling resources. In order to teach for social justice, within our classrooms we should explore and pursue a learner-centred pedagogy focused on the students' knowledge base, the strategic processing of their thoughts, motivation and development and a reflective understanding of their educational and social identities within the institution. Our aims as teachers and researchers should be to collectively engage the knowledge and experiences of our students and local communities to enable them to author and construct their own identities as future leaders and professionals in economic, civil and political spheres.

From our vantage point as progressive teachers and researchers we need to take note of the tacit knowledge and experiences that constitute the individual and collective voices that our students use to interrogate their lived experience. Such a stance will enable us to combat any form of oppression experienced by individuals as members of various ethnic/racial, language, social class and other groups that are rooted in particular institutional and social structures 
(Zeichner \& Flessner, 2009:26). Whatever our arguments, the only certainty is the proliferation of new knowledge that should breed a scholarly mindset. Thus through our teaching and learning and knowledge currencies, individuals and the university are compelled to reinvent themselves, their operating and surrounding community environments, and ways of learning and utilising new information to reinforce a scholarship mindset so as to build new information and relevant knowledge.

\section{Conclusion}

In a globalised and globalising knowledge economy, we are continually challenged to transform teaching and learning by providing epistemological access to address the academic needs of our students and to be responsive to societal interests in terms of knowledge, technology innovation and human resources; to address equity and quality issues as well as redress in terms of gender and class; and more importantly, to bridge the gap between research and teaching. Our quest should therefore include the effort to teach our students the requisite skills and knowledge and to imbue them with the attitudes and values that will enable them to function successfully and to contribute meaningfully within our knowledge-intensive, knowledge-based economy and transforming global society. This has far-reaching implications for graduateness at the university in terms of the quality of competencies and capabilities as well as the generic skills that our students would have attained on completion of their studies to enhance their potential for future employment, contribution to economic growth, poverty eradication, social justice and lifelong learning.

Therefore, in our quest to develop the scholarship of teaching and learning we need to argue for a critical pedagogy that de-centres the teacher and re-centres the student as the subject of educational practice in order to recognise, engage and critique so as to transform any undemocratic social practices and institutional structures that produce and sustain inequalities and oppressive social identities and relations (Zeichner \& Flessner, 2009:29). Furthermore, the change to a global education system and the parallel development of a knowledge and information economy inevitably creates a new scenario in terms of the development of the scholarship of teaching and learning within the institution under study. Our role is to contribute to the ongoing debates on how to improve student learning and outcomes, particularly because South Africa is considered to be internationally lagging behind in educational outcomes. Moreover, with the understanding that universities of technology are loosely coupled systems which continually import and export energy in order to change, develop and be relevant to contextual needs, we believe that it is essential to create knowledge and disseminate it amongst our students and broader society in order to optimise the impact of our efforts in the classroom.

To prepare for a fiercely competitive global economy, Astin (1993) suggests that the amount of student learning and personal development should be directly proportional to the quality and quantity of student involvement in the process of learning, including participation in leadership experiences in the social justice agenda. The challenge for us is to link our pedagogy with these influences and to reflect continually on the ten South African values, namely, democracy, equality, an open society, Ubuntu, respect, social justice and equality, non-racism and non-sexism, accountability, the rule of law and reconciliation. We ought to keep these values in mind as we work with the curriculum, the students and broader society. This requires the development of a vision for scholarship that should be able to plant an image in consciousness that provokes deep feelings and stirs a sense of possibilities and inner commitment towards helping our students. Indeed, scholarship unifies diverse students and teachers around a shared aspiration and clarifies direction in the face of shifting agendas for social justice and quality learning in higher education (Zeichner \& Flessner, 2009:24). Scholarship in this context refers to a progressive social-reconstructionist-oriented teacher-student-community agenda that enables us to work against inequalities in education.

Hopefully, the continued debates on SoTL will enable those of us who have a vested interest in teaching and learning to cultivate sound scholarly habits of mind and heart that will create original insights that enlighten humanity; it is possible that this may arise from a rigorous and scholarly environment. Ironically, on the other hand, the goals of teaching will remain largely the same, that is, to nurture in students the capacity for independent critical thought and perhaps even a desire to continue learning throughout their lives. Students will also continue to seek out inspiring teachers. Technology alone is unlikely to ensure this, although it may make a lot of average teachers seem a lot better than they are.

\section{References}

Apple, M.W. 2004. Curriculum and ideology. $3^{\text {rd }}$ ed. New York: Routledge.

Arshad-Ayaz, A. 2008. From producing citizens to producing managers: Education in a globalized world. In Hopson, R.K.; Yeakey, C.C. 
\& F.M. Boakari (Eds.). Advances in diverse communities: Research policy and praxis. Power, voice and the public good: Schooling in global societies. Volume 6. United Kingdom: Emerald, pp.480-506.

Astin, A.W. 1993. What matters in college? Forum critical years revisited. San Francisco: Jossey-Bass.

Boyer, E. L. 1990. Scholarship reconsidered: Priorities of the professoriate. San Francisco: Jossey-Bass.

Breslow, L.; Drew, L.; Healey, M.; Matthew, B. \& Norton, L. 2004. Intellectual curiosity: a catalyst for the scholarship of teaching and learning and educational development, In Elvidge, L. (Ed.). Exploring academic development in higher education, Issues of engagement. Cambridge: Jill Rogers Associates, pp. 83-96.

Brookefield, S.D. 2005. The skillful teacher. San Francisco, CA: Jossey-Bass.

Brooks-Buck, J. 2008. Schools as markets: bilking the young and powerless. In Hopson, R.K.; Yeakey, C.C. \& F.M. Boakari (Eds.). Advances in diverse communities: Research policy and praxis. Power, voice and the public good: Schooling in global societies. Volume 6. United Kingdom: Emerald, pp.117-148.

Council on Higher Education. 2013. A proposal for undergraduate curriculum reform in South Africa: The case for a flexible curriculum structure. Report of the Task Team on Undergraduate

Elton, L. 2001. Research and teaching: What are the relationships? Teaching in Higher Education, 6 (1), 43-56.

Elton, L. 2003. Some thoughts on scholarship. Educational Developments, 4 (4): 7-8.

Elvidge, L. (Ed.). 2004. Exploring academic development in higher education: Issues of engagement. Cambridge: Jill Roger Associates.

Fisher, G. \& Scott, I. 2011. The role of higher education in closing the skills gap in South Africa. Background Paper 3 for 'Closing the skills and technology gap in South Africa'. Washington D.C.: The World Bank.

Gibbs, G. \& Habeshaw, T. 2002. Recognising and Rewarding Excellent Teaching. Milton Keynes: TQEF National Co-ordination Team. Available from: http://www.heacademy.ac.uk/documents/GPGuide_RRET.pdf

Glasner, A. 2003. Can all teachers aspire to excellence? Exchange, 5:11. Available from: www.exchange.ac.uk/issue5.asp

Green, D.A. \& Little, D. 2013. Academic development on the margins. Studies in Higher Education, Vol. 38 (4), pp. 523-537.

Healey, M. 2000. Developing the scholarship of teaching in higher education: a discipline-based Approach. Higher Education Research \& Development, Vol. 19, №. 2, pp. 171-189.

Healey, M. 2005. Linking research and teaching exploring disciplinary spaces and the role of inquiry based learning, In Barnett, R. (Ed.). Reshaping the new relationships between research, scholarship and teaching. Maidenhead: McGraw-Hill/Open University Press, pp. 30-42.

Hooks, B. 1990. Talking back. In Out there: marginalization and contemporary cultures, R. Ferguson; M.Gever; T.T. Minh-ha \& C. West (Eds.). Cambridge, MA: MIT Press. pp. 337-43.

Hutchings, P. 2002. Informal hand-out and remarks at the SoTL Community of Practice. Annual meetings of the American Association of Higher Education. Chicago, March.

Hutchings, P; Huber, M.T. \& Ciccone, A. 2011. The scholarship of teaching and learning Reconsidered: Institutional integration and Impact. New York: Jossey-Bass.

Hutchings, P. \& Shulman, L. S. 1999. The scholarship of teaching: New elaborations, new developments. Change, 31 (5):10-15.

Joshee, R. 2008. Neoliberalism versus social justice: A view from Canada. In Hopson, R.K.; Yeakey, C.C. \& F.M. Boakari (Eds.). Advances in diverse communities: Research policy and praxis. Power, voice and the public good: Schooling in global societies. Volume 6. United Kingdom: Emerald, pp. 31-54.

Kreber, C. (2002) Teaching excellence, teaching expertise, and the scholarship of teaching. Innovative Higher Education, 27 (1): 5-23.

Kreber, C. 2005. Charting a critical discourse on the scholarship of university teaching movement. Studies in Higher Education, 30 (4), pp. 389-405.

Little, B.; Locke, W.; Parker, J. \& Richardson, J. 2007. Excellence in teaching and learning: a review of the literature for the Higher Education Academy. Centre for Higher Education Research and Information. The Open University.

McKinney, K. 2004. The scholarship of teaching and learning: past lessons, current challenges, and future visions. In C. Wehlburg \& S. Chadwick- Blossey (Eds.), To improve the Academy, 22: 3-19. Bolton, MA: Anker Publishing Company.

Miah, A. 2012. Media2012 - Interview with Professor Andy Miah about the London 2012 Olympics \& Paralympic games. The NewsMeback Blog. Citizen Journlism Blog. April 11, 2012.

National Planning Committee (NPC) 2012. National Development Plan 2030: our future - make it work. Pretoria: The Presidency: National Planning Commission.

Portes, R.P. 2005. Dismantling educational inequality. A cultural-historical approach to closing the achievement gap. New York: Peter Lang.

Schon, D.A. 1983. The reflective practitioner: How professional think in action. New York: Basic Books.

Skelton, A. 2005. Understanding teaching excellence in higher education: towards a critical approach. London: Routledge Falmer.

Shulman, L.S. 2001. Remarks at the teaching symposium for the Cross Endowed Chair for the scholarship of Teaching and Learning. Illinois State University, Norman, IL.

Shulman, L.S. 2005. Signature pedagogies in the professions. Dadalus, 134: 52.59.

Zeichner, K.M \& Flessner, R. 2009. Educating teachers for social justice. In K.M. Zeichner (Ed.). Teacher education and the struggle for social justice, New York: Routledge. pp. 24-43.

Zubrick, A.; Reid, I. \& Rossiter, P. 2001. Strengthening the nexus between teaching and research. Canberra: Australian Department of Education, Training and Youth Affairs. Available from: http://www.dest.gov.au/archive/highered/eippubs/eip01 2/01 2.pdf. Accessed: 23/9/2013. 
